\title{
THE LITERARY QUALITY OF SCRIPTURE AS SEEN BY THE EARLY CHURCH
}

\author{
Michael Graves
}

\begin{abstract}
Summary
Christians in the first five centuries of the church lived in an environment that placed a high value on literary and rhetorical expression. Within this context, cultured critics of Christianity often disparaged the literary style of the Christian Bible in its Greek and Latin forms. The most common response in the first Christian centuries was to concede Scripture's simple style but to assert the superiority of its divine content. But eventually Christians began to suggest paradigms for seeing artistic crafting in the biblical text. One stream of thought, exemplified by Jerome, looked to the original language of the Old Testament to discover the literary quality of Scripture. Another stream of thought, developed by Augustine, explored the literary quality of Scripture by reflecting on the relationship between human conventions and divine inspiration.
\end{abstract}

\section{Introduction}

The Christian church came into being and developed within a cultural context that cared deeply about the stylistic qualities of language. When confronted with the claims of the Gospel, educated Romans wanted to know how the sacred writings upon which the Gospel was based compared to the great literary works that set the standard for Graeco-Roman high culture. Educated Christians responded to this challenge partly for apologetic reasons, and partly because they, too, felt the need to explain why their Scriptures seemed different from the pagan classics. Fortunately, the Roman cultural context not only demanded an explanation, it also provided the tools to formulate one. Early Christians took the tools of Graeco-Roman criticism and used 
them to make important observations about the literary quality of Scripture. They also made significant contributions to the theology of Scripture by describing the artistic nature of biblical writings in light of their divine inspiration. In the end, Graeco-Roman culture provided the intellectual framework that enabled Christians to go beyond GraecoRoman conventions in their thinking about the artistic nature of Scripture.

My first task will be to paint a brief picture of the literary culture of the Graeco-Roman world and the negative reception that the Bible received when it first entered that world. Then, I will consider the various responses given by different Christians to this negative reception. In the earliest centuries, Christians conceded that their sacred writings were not great literary art (as seen from the Graeco-Roman viewpoint), but argued that that was not their purpose. In later centuries, Christians defended the literary quality of Scripture by reaching beyond standard Graeco-Roman cultural conventions in their assessment of biblical texts. We will examine two streams of this defence, the first a Hebrew-based argument exemplified by Jerome, and the second an argument based on convention and inspiration formulated by Augustine. I will conclude by drawing together these observations and highlighting some aspects of the enduring value of the early church's conception of the literary quality of Scripture.

\section{Graeco-Roman Literary Conventions and the Greek Bible}

By the Third Century BC when biblical writings first came to be known in the Greek world, ${ }^{1}$ definite conventions had already developed for writing and reading literature. Self-conscious literary theory received its firmest foundation among the Greeks from Aristotle, who described the aesthetics of poetry (defined as mimetic art employing speech) in his Poetics, and outlined the principles of persuasive speech in his Rhetoric. Aristotle discussed the different genres of poetry and the types of rhetoric, and he also set forth for both kinds of discourse

\footnotetext{
1 According to our earliest source, the Letter of Pseudo-Aristeas, the Pentateuch was translated into Greek in the Third Century BC; see Natalio Fernández Marcos, The Septuagint in Context: Introduction to the Greek Versions of the Bible (tr. W. G. E. Watson; Leiden: Brill, 2001): 18-21, 35-66.
} 
an understanding of the proper use of language, both in the selection and in the arrangement of words. During the Hellenistic period, scholars associated with the library at Alexandria wrote commentaries on the great works of the past and even established lists of the best authors and their most important compositions. ${ }^{2}$ Greek literary criticism continued to develop into the Roman era and was adopted and refined by Roman critics. Poetry was usually the first to receive attention, but the qualities of prose authors were also discussed, including the writers of philosophical dialogues and treatises, historical works, formal letters and speeches. ${ }^{3}$ Literary theorists categorised and prescribed rules for various tropes and figures; ${ }^{4}$ they created categories for different styles, such as the threefold system of 'grand', 'simple', and 'florid;' 5 and they listed virtues of style, such as clarity, grandeur, beauty, conciseness and 'correct usage' (latinitas, 'E $\lambda \lambda \eta$ viouós). ${ }^{6}$ Although the Graeco-Roman system of language style was not uniform, it did constitute a relatively coherent tradition from the time of Aristotle down to the early Byzantine era.

The Greek Bible, as a translation from a foreign (in this case, Semitic) original, was something of an alien entity as a literary composition in the Greek world. ${ }^{7}$ In spite of this, the first pagan author to quote a biblical text praised its manner of expression. 'Longinus' (perhaps First Century AD?) in his work On Sublimity praised the literary quality of the beginning of Genesis for its representation of the

2 R. Pfeiffer, History of Classical Scholarship: From the Beginning to the End of the Hellenistic Age (Oxford: Clarendon Press, 1968): 206-208.

3 Cf. Cicero, Orator, 61-66; and Demetrius, On Style, 223-35. On ancient literary criticism, see D. A. Russell, Criticism in Antiquity (London: Gerald Duckworth \& Co., 1981); and G. M. A. Grube, The Greek and Roman Critics (London: Methuen, 1965). On the conventions of ancient rhetoric, see George A. Kennedy, A New History of Classical Rhetoric (Princeton, NJ: Princeton University Press, 1994).

4 See Rhetorica ad Herennium, 4.12.18-4.55.69; Cicero, De oratore, 3.149-72; Quintilian 8.6-9.3; 'Longinus', On Sublimity, 16.1-29.2.

5 See Dionysius of Halicarnassus, Demosthenes, 1-3; Quintilian, 12.10.58-65; Cicero, Orator, 21.69-70; Aulus Gellius, Attic Nights, 6.14.1-11. A fourfold system of styles is found, for example, in Macrobius, Saturnalia, 5.1.7.

6 See Aristotle, Poetics, ch. 22, 1458a-1459a; Rhetoric Bk. 3, chs. 5-7, 1407a-1408b; Hermogenes, On Types, 217-18; and Dionysius of Halicarnassus, Lysias, 13. On 'correct usage', see Heinrich Lausberg, Handbook of Literary Rhetoric: A Foundation for Literary Study, ed. D. E. Orton and R. D. Anderson (tr. M. T. Bliss, A. Jansen, and D. E. Orton; Leiden: Brill, 1998): §§ 463-527.

7 Cf. Sebastian Brock, 'The Phenomenon of Biblical Translation in Antiquity' in Studies in the Septuagint: Origins, Recensions, and Interpretations, ed. H. M. Orlinsky (New York: KTAV, 1974): 541-71. 
divinity [following a description of Poseidon from the start of Iliad 13]: 'A similar effect was achieved by the lawgiver of the Jews-no mean genius, for he both understood and gave expression to the power of the divinity as it deserved - when he wrote at the very beginning of his laws, I quote his words: "God said"-what? "Let there be light. And there was. Let there be earth. And there was" (Sub 9:9). ${ }^{8}$

In general, however, the reception of the Greek Bible in GraecoRoman antiquity was not favourable towards its literary merits. For example, Celsus compared even the best passages in Christian Scripture - as might impress an intelligent person-with the works of Plato, and concluded that 'these ideas have been better expressed among the Greeks' (Cels 6:1). According to Origen (c. 185-251), Celsus and others said that 'the scriptures have a mean style, which appears to be put in the shade by the brilliance of a literary composition' (Cels 6:2). ${ }^{9}$ Arnobius (d. c. 327) preserves the charge of an early critic of Christianity: 'the language [i.e. of the Scriptures] is commonplace and of low quality ... Your narratives ... are overrun with barbarisms and solecisms and vitiated by ugly faults' ( $A$ g. P. 1:5859). ${ }^{10}$ Lactantius (c. 250-325) explains that 'for those accustomed to sweet and polished speeches and songs, they spurn the simple and direct speech of the divine writings as mean' (Div. Inst., 6:21). ${ }^{11}$ The emperor Julian (331-63) mocked the Old Testament because it had originally been written in Hebrew, which was considered an inelegant language. ${ }^{12}$ As a general rule, in the first four centuries of Christianity educated readers looked unfavourably upon the literary quality of the Greek Bible, especially in comparison with the pagan classics.

The reasons for this negative reception are easy to understand. First, the literary genres of most biblical books were unfamiliar to the

8 The English translation is that of D. A. Russell; see Menahem Stern, ed., Greek and Latin Authors on Jews and Judaism (Jerusalem: Israel Academy of Sciences and Humanities, 1974): 1:361-65. The quotation is obviously inexact.

9 Henry Chadwick, Origen: Contra Celsum: Translated with an Introduction and Notes (Cambridge: Cambridge University Press, 1965): 316.

10 Arnobius of Sicca, The Case against the Pagans (tr. George E. McCracken; New York: Newman Press, 1949): 1:104.

11 Lactantius, The Divine Institutes (tr. Mary Francis McDonald; Washington, DC: Catholic University of America Press, 1964): 455.

12 See Cyril of Alexandria, Against Julian, 7.233-34 (PG 76, 857). On the perceived roughness or inelegance of Hebrew from the Greek (and Latin) perspective, see the discussion of Jerome below. 
Graeco-Roman world. ${ }^{13}$ Second, in its Greek and Latin forms, the Old Testament was indeed written in somewhat shabby language according to the stylistic tastes of the day, and the same could be said of much of the New Testament in the original. The gap between biblical Greek style and what learned people expected in great literature may be seen in the story of two Christians named Apollinaris (father and son) who lived during the reign of the Emperor Julian (361-63). One of the measures taken by Julian against the Christians was to forbid them from teaching in the schools. If the Christians did not believe in the pagan religion, reasoned Julian, they should not teach the classical texts upon which that religion was founded. ${ }^{14}$ But Christian leaders of the Fourth Century were not willing to be deprived of the use of cultured Greek. Gregory of Nazianzus asserted that the Greek language did not belong exclusively to pagan religion and rejected Julian's belief that 'in using Greek language we are stealing what belongs to others' (Or., 4:5). ${ }^{15}$ In order that Christians might be able to teach and learn all of the forms of classical Greek literature, the two Apollinares produced paraphrases of biblical books in classical forms, such as Moses in hexameters, historical books in dactylic measure or in tragic form, and the Gospels as Platonic dialogues. ${ }^{16}$ This gives a sense of what the Greek Bible would have needed to look like in order for it to have met contemporary standards. ${ }^{17}$ It seems clear that it did not. This negative

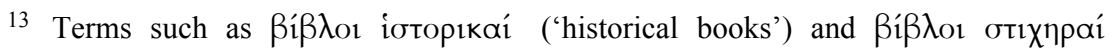
('books in verse') used in ancient lists of biblical books show that Greek Christians were attempting to think about biblical literature through the lens of Greek genres; see H. B. Swete, An Introduction to the Old Testament in Greek (rev. by R. R. Ottley; Cambridge: Cambridge University Press, 1914): 204-213.

14 Julian, Ep. 36: 'let them (i.e. the Christians) betake themselves to the churches of the Galilaeans to expound Matthew and Luke'; see The Works of the Emperor Julian (tr. W. C. Wright; Cambridge, MA: Harvard University Press, 1923): 3:121.

15 See Robert L. Wilken, The Christians as Romans Saw Them (2nd edn; New Haven, CT: Yale University Press, 2003): 174-75.

16 Socrates Scholasticus, Ecclesiastical History, 3.16. Sozomen (Ecclesiastical History, 5.18) adds that the Homeric-style poem in hexameters went all the way to the reign of Saul, and that Apollinaris (the elder) broke this work up into twenty-four parts in imitation of Homer's works. Jerome mentions a priest named Iuvencus who composed an edition of the four Gospels in hexameters (Chronicon AD 329; De vir. Ill., 84).

17 Poetry in ancient Greek thinking was more than simply language in metre, although this is one way that it was described; see Russell, Criticism in Antiquity, 22-23; and Ernst Curtius, European Literature and the Latin Middle Ages (tr. Willard R. Trask; Princeton, NJ: Princeton University Press, 1953): 147-48. Cf. also the rebuke of pagan arrogance found in the anonymous Christian work Exhortation to the Greeks, 38: 'the essentials of the true religion are found neither in poetic metres nor in your greatly 
reaction to the literary form of Scripture became the starting point for Christian reflection on the possible literary quality of biblical books.

\section{The First Christian Response: Content over Form}

The most common response among Christians was to concede the lack of artistic quality in Scripture and to offer an explanation for it. As one argument, it was asserted that Scripture's lowly language expressed the Christian virtue of humility. Second-century Tatian claims that he was persuaded of the truth of the Christian faith not only by the doctrines and prophetic utterances of Scripture, but also by its humility, 'the lack of arrogance in the wording, the artlessness of the speakers' (Or. Gr., 29). ${ }^{18}$ Similarly, Clement of Alexandria says that the divine Scriptures raise humanity out of evil, frivolity and deceit because they lack embellishment, seductiveness, and the outward beauty of diction and wordiness (Protr., 8).

Another way to approach the problem was to emphasise content over form. Origen argues that the content of Scripture does not suffer from the fact that the holy writers committed solecisms, ${ }^{19}$ and he cites 1 Corinthians 2:4 and 2 Corinthians 11:6 in order to remind his readers that the Apostle Paul acknowledged his lack of rhetorical sophistication. ${ }^{20} \mathrm{He}$ then concludes:

For had the Scripture been embellished with elegant style and diction, like the masterpieces of Greek literature, one might perhaps have supposed that it was not the truth which got hold of men, but that the

esteemed culture; you should pay less attention to accuracy of metre and language'. The work was attributed to Justin Martyr, but the actual author is unknown; see Saint Justin Martyr (tr. Thomas B. Falls; New York: Christian Heritage, 1948): 422.

18 Tatian: Oratio ad Graecos and Fragments (tr. Molly Whittaker; Oxford: Clarendon Press, 1982): 55.

19 Philokalia, 4.1; see The Philokalia of Origen (tr. George Lewis; Edinburgh: T \& T Clark, 1911).

20 Origen was generally content to concede that Paul had not written in a polished style (e.g. Comm. Rom., pref.; 6.3.2), insisting rather that Paul wrote with profound 'knowledge' (Comm. Rom. 4.11.2). Still, in his Comm. Rom. 6.13.2 Origen suggests that Paul may have made use of a syllogism, although he chooses not to discuss it lest he appear to be defending Paul's words rather than his knowledge. Moreover, on 1 Cor. 15:14 Origen proposes that Paul may have employed 'dialectical discourse', but (according to Origen) Paul would have done so by nature, not by training; see p. 177, n. 48 . 
clear sequence of thought and the beauty of the language won the souls of the hearers, and caught them with guile. ${ }^{21}$

In other words, the humble style of Scripture was specifically intended to give prominence to the message. As Origen explains elsewhere, the lack of rhetorical sophistication on the part of Jesus' followers demonstrates that their success in persuading people came not from human ingenuity but from divine power. ${ }^{22}$ John Chrysostom (ca. 347407) makes the same argument in his second homily on the gospel of John: although it is true that the disciple John was an uneducated fisherman, this actually proves the divine origin of the lofty doctrines about which he wrote, since apart from divine instruction there is no way that he could have learned them. Chrysostom then promises: 'We shall not see noise of words or pomposity of style, or careful ordering and artificial, foolish arrangement of nouns and verbs ... but invincible and divine strength, irresistible power of authentic doctrines, and a wealth of good things without number.'23

As another approach, it could be argued that the purpose of Scripture's 'popular' style (as it appeared in Greek and Latin) was to communicate the truth to a wide audience. Origen justifies the literary quality of the apostle's writings in this way:

We say that it is the task of those who teach the true doctrines to help as many people as they can, and as far as it is in their power to win everybody over to the truth by their love of humankind - not only the intelligent, but also the stupid, and again not just the Greeks without

21 Origen, Philokalia, 4.2. As part of his argument, Origen applies the metaphor of 'treasure in earthen vessels' (cf. 2 Cor. 4:7) to Scripture: the treasure is the knowledge and hidden wisdom contained in Scripture, and the earthen vessels represent the contemptible diction, from the Greek perspective, in which Scripture is written. Origen often appealed to this Pauline metaphor in order to explain how the lofty content of Scripture could be contained in a humble style (e.g. Princ., 4.1.7; 4.3.14); see M. F. Wiles, The Divine Apostle (Cambridge: Cambridge University Press, 1967): 16. Jerome borrows this analogy at Hom. Ps. 11, where the treasure is the content and the earthen vessels are the 'homely words of the Scriptures'; see The Homilies of Saint Jerome (tr. Marie L. Ewald; Washington, DC: Catholic University of America Press, 1964): 1:84.

22 As Origen says, Jesus' followers had 'no power of speaking or of giving an ordered narrative by the standards of Greek dialectical or rhetorical arts', since they were 'fisherfolk and tax-collectors who had not had even a primary education', and yet they succeeded in persuading not only the Jews but also other nations (Cels., 1.62).

23 John Chrysostom, Commentary on Saint John the Apostle and Evangelist (tr. T. A. Goggin; New York: Catholic University of America Press, 1957): 18. The idea that the apostles were uneducated simpletons was a common theme in early charges against Christianity; see John G. Cook, The Interpretation of the New Testament in GrecoRoman Paganism (Tübingen: J. C. B. Mohr, 2000): 263-65. 
including the barbarians as well. It is a very excellent thing if someone is able to convert even the most stupid and uneducated yokels. Obviously, therefore, when such teachers speak they have to take pains to use a type of vocabulary that will help everybody and can command a hearing with anyone. (Cels., 6:1).

The same basic argument can also be found in Lactantius: 'This reason is one of the first why the wise and learned people and the princes of this world do not place any sacred trust in the Scriptures; the fact that the prophets spoke the common and simple speech, as though they were speaking to the people' (Div. Inst., 5:1:15-16). John Chrysostom's treatment of the apostle Paul also reflects this perspective on the style of Scripture. While Chrysostom repeatedly affirms Paul's lack of education and skill in rhetoric, he also praises Paul for his ability to persuade. ${ }^{24}$ Even if Paul's style was not elegant, the discourse of his teaching was well suited to convince people of the truth of the Gospel. $^{25}$

Thus, according to this line of patristic thought, the low style of Scripture is not a problem but an asset. The humility of the speech matches the humility of the Christian calling. The truth and divine power of Scripture are clearly shown because people responded to the message of Scripture and not its style. And the popular style of the language was specially suited to reach the greatest number of hearers, excluding only the proud who refuse to listen. Especially in the early centuries of the church, reflection on the literary quality of Scripture took the form of arguments such as these.

24 On Chrysostom's disparagement of Paul and his education, see Sac., 4.6; Hom. 2 Tim. 2:10; Hom. Gal. 6:11-12; Hom. Rom. Arg. Chrysostom's positive assessments of Paul's persuasive abilities have been highlighted by Margaret Mitchell, The Heavenly Trumpet (Louisville: Westminster John Knox, 2002): 242-43, 278-82.

25 See especially Chrysostom, Hom. Rom. Arg.: 'For this man's tongue shone forth above the sun, and he surpassed all others in the discourse $(\lambda$ ó $\omega)$ of teaching; for since he labored more abundantly than they, he also drew upon himself a large measure of the Spirit's grace. And this I affirm not only from the Epistles but also from the Acts. For if there were anywhere an occasion for a public speech ( $\delta \eta \mu \eta \gamma o p i a s)$, people everywhere gave place to him.' See Saint John Chrysostom: Homilies on the Acts of the Apostles and the Epistle to the Romans (tr. J. B. Morris and W. H. Simcox, rev. G. B. Stevens; New York: Christian Literature Publishing, 1889; reprint edition, Grand Rapids: Eerdmans, 1969): 335-36, slightly revised. 


\section{Defence of Scripture as Artistic Literature}

Beginning in the Fourth Century some Christian thinkers who loved great literature began to consider the idea that biblical texts could represent great literature in their own way. Because the Fourth Century was the era of the Christianisation of the Empire, it is possible to see arguments for the literary merits of Scripture as simply part of the rhetoric of the cultural shift that was putting Christianity at the centre of power. But it is also logical that, as Christian culture developed in the wake of the end of persecution, Christian thinkers enjoyed more time and freedom to reflect on the literary merits of their sacred writings. I will trace two different lines of thought by which Christians began to see scriptural texts as great literature. In each case, the particular literary qualities of specific biblical books and genres receive greater attention, and the basic principle is asserted that one must appreciate biblical writings on their own terms.

\section{The Hebrew Original}

The first line of thought began with Origen. Although Origen was one of those who best articulated the reasons why Scripture was written in simple language, the alternative view, that Scripture really does have artistic quality, can also be traced back to him. In Contra Celsum 7:59, after referring to the "poorer language and simpler style used by Jews and Christians' in comparison with the beauty of Greek literature, Origen says: 'In any event, the original words of the Jews, which the prophets used in the books which they have left to us, were written in the Hebrew language; and they made an artistic use of the literary style of their language'. Following Origen, Eusebius (c. 260-339) picked up the idea that the Old Testament was well composed in the original Hebrew, stating in Preparation for the Gospel 11:5:2 that the Hebrews had written psalms and other poems 'in metre', with 'beauty of language' and 'eloquent recitation in their own tongue'. ${ }^{26}$ Jerome (c. 347-419), a lover of great literature and a Latin-Greek bilingual with a keen sense of language, continued this line of thinking and took the enterprise to a new level by actually learning to read Hebrew.

26 Eusebius, Preparation for the Gospel (tr. E. H. Gifford; Oxford: Clarendon Press, 1903): 2:550. 
Jerome's initial reaction to the Old Testament as literature was not positive. ${ }^{27}$ In Epistle 22, before reporting his famous dream (in which he is flogged by an angel for loving classical literature too much), Jerome says that his early assessment of the prophets was that 'their style seemed rude and repellent' (Ep. 22:30). His first encounters with the Hebrew language did not impress him in terms of elegance and beauty: 'After having familiarized myself with the pointedness of Quintilian, the fluency of Cicero, the seriousness of Fronto, and the gentleness of Pliny, I began to learn my letters anew and to study to pronounce words both harsh and guttural' (Ep. 125:12). Yet, once he acquired some proficiency in Hebrew, he realised that Hebrew has its own kind of literary quality, which naturally does not come through in translation. Early in his serious study of Hebrew, while discussing the basic difficulty that a translator faces in trying to render the literary beauty of any work into a second language, Jerome explained that the Old Testament only seemed like bad literature to learned men because it was not actually written in Greek or Latin, but in Hebrew: 'Thus it has come about that the sacred writings appear less adorned and lyrical, because the aforementioned men are unaware that they have been translated from Hebrew ... What is more melodious than the Psalter? What is more beautiful than the songs of Deuteronomy or Isaiah? What is more elevated than Solomon? What is more polished than Job? ${ }^{28}$ By reading the Old Testament in Hebrew, Jerome overcame his initial dislike of the Old Testament as literature.

Jerome developed his literary sensibilities early in life through his formal education, the high point of which was his time as a teenager studying in Rome with the famous grammaticus, Aelius Donatus. Part of the 'grammatical' model of scholarship in late antiquity involved aesthetic appreciation of the text, and although his primary interest in the biblical text was its moral or theological teaching, ${ }^{29}$ Jerome also

27 Jerome also commented on the forcefulness but lack of elegance found in Paul: 'His words seem simplicity itself: the expressions of a guileless and unsophisticated person - one who has no skill either to plan a dilemma or to avoid it. Still, whichever way you look, they are thunderbolts' (Ep. 48.13). The Principal Works of St. Jerome (tr. W. H. Fremantle; New York: Christian Literature Publishing, 1893; reprint edition, Grand Rapids: Eerdmans, 1979): 73.

28 Rudolf Helm, ed., Eusebius Werke, Siebenter Band: Die Chronik des Hieronymus (GCS 47; Berlin: Verlag, 1956): 3-4.

29 On Jerome's use of the classical literary model of scholarship, see Michael Graves, Jerome's Hebrew Philology (Leiden: Brill, 2007): 13-75. 
read Scripture with an eye towards its beauty, especially (but not only) with regard to Hebrew matters. Jerome found both well-constructed content and delightful language in the Old Testament.

For example, Jerome refers to at least fifteen Greek literary terms in his commentaries on the Old Testament, including пробштотоӥ $\alpha$

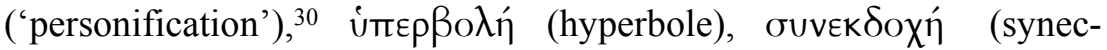

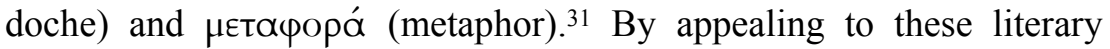
figures to explain the biblical text, Jerome is showing his belief in the artistic quality of the Old Testament in Hebrew. When Isa. 23:4 introduces the sea as a speaker, Jerome identifies this as a case of тробштотоиіа ('personification'). ${ }^{32}$ In his commentary on Jeremiah 11:5, Jerome explains that the promise to give Israel 'a land flowing with milk and honey' was really úmepßo $\lambda \dot{j}$ (hyperbole) for an abundance in all things, and he illustrates this figure by citing Virgil's Eclogues 3:89 and Georgics 1:132. ${ }^{33}$ When Jeremiah complains that he will be judged by the whole earth (Jer. 15:10), Jerome says that this is

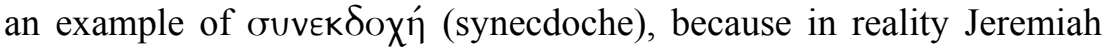
was not judged by the whole earth but by Judaea alone. Jerome refers

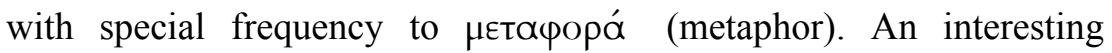
example occurs at Comm. Jer. 6:2-3, where Jerusalem is likened to a lovely maiden, and it is then predicted that the desolation of the city will be so complete that shepherds will graze their flocks within it. Jerome reads verse 6:2 as 'I have likened my daughter Zion to a fair and delicate maiden'. In view of the two literary figures presented in the passage, the metaphor of the maiden and the image of the desolate and shepherd-filled city, Jerome praises the elegance of רעים (RSV: 'Shepherds') in verse three: 'Very elegantly in the Hebrew the word is written with four letters: "res, ain, iod, mem". If it is read "reim", it means "lovers", but if it is read "roim", it means "shepherds", so that one may understand either "lovers" of the beautiful maiden according to the metaphor, or "shepherds" of the city in accord with the desolation of the city'. Jerome believes that the ambiguity in the

\footnotetext{
$30 \pi$ пробштопоita is the introduction of non-personal things as speakers. It is therefore not strictly the same as personification, but is more like a sub-species of personification.

31 Graves, Jerome's Hebrew Philology, 48.

32 M. Adriaen, ed., S. Hieronymi Presbyteri Commentariorum in Esaiam Libri I-XI (CCSL 73; Turnholt: Brepols, 1963): 218.

33 Siegfried Reiter, ed., Sancti Eusebii Hieronymi in Hieremiam Prophetam Libri Sex (CSEL 59; Leipzig: Freytag, 1913): 141-42.
} 
pronunciation and meaning of the Hebrew adds an artistic quality to the passage. ${ }^{34}$

Jerome showed a solid grasp of the artistic capabilities of the Hebrew language. Hebrew has a rich capacity for assonance and word plays, and Jerome was clearly aware of this. Thus, in his Comm. Isa. 5:7c, 'He looked for justice (משפט), but behold, bloodshed (משפח); for righteousness (צדקה), but behold, a cry! (צעקה)', Jerome explains the wordplays thus: 'And so with one letter being either added or altered thus, he properly mingled the similarity of the words, so that for "mesphat" he said "mesphaa", and for "sadaca" he put "saaca", and he produced an elegant structure and sound of the words according to the Hebrew language'. Likewise, in the Hebrew Questions on Genesis, at 49:19 ('Gad, a brigand shall rob him; and he himself shall rob the sole of the foot'), Jerome makes this observation: 'We have translated according to the Hebrew. But where we have put "brigand", "gedud" is written in that place, so as to pun on the name "Gad." 35 Jerome's manner of appreciating the Hebrew Bible can be summed up in his comment on Isaiah 22:6: 'elegantly it resounds in Hebrew, and also the sense is most beautiful'. Jerome's commentaries never lose their focus on the content of the biblical text, but they also show his awareness and appreciation of the artistic qualities of the Hebrew.

Jerome represents the high point in the first line of argument in defence of Scripture (specifically, the Old Testament) as artistic literature. Following tracks laid by Origen and Eusebius, Jerome demonstrated more than any other that the Old Testament was artistic when read in the original Hebrew. How far Jerome's appreciation for Hebrew had come can be seen from his remark that many Hebrew words had been merely transliterated into Greek and Latin 'because of the difficulty of interpretation and the poverty of both the Greek and Latin languages in comparison with the Hebrew language' (Comm. Isa. 40:12-17). ${ }^{36}$ This is quite a statement to make for someone who had been trained in an elitist Graeco-Roman literary culture.

34 In Hebrew the vowels are not written, but they affect the meanings of the words. The word in question, as written on the page, could be pronounced in two ways, each of which yields a meaning appropriate to the context. Jerome regards this as a literary feature of the passage.

35 C. T. R. Hayward, Jerome's Hebrew Questions on Genesis: Translated with an Introduction and Commentary (Oxford: Clarendon Press, 1995): 86.

36 On the the extent and limits of Jerome's Hebrew knowledge, see Hillel Newman, 'How Should We Measure Jerome's Hebrew Competence' in Jerome of Stridon: His 


\section{Convention and Inspiration}

In addition to the Hebrew-based approach of Origen, Eusebius and Jerome, there was a second approach to finding literary art in Scripture that tried to show that biblical writings (even in translation) did possess conventional Graeco-Roman literary qualities, although in a distinctive way. The foundations of this line of argument can be seen in a letter written in c. 381 by Ambrose:

Many persons say that our sacred writers did not write in accordance with the rules of rhetoric. We do not take issue with them: the sacred writers wrote not in accord with rules, but in accord with grace, which is above all rules of rhetoric. They wrote what the Holy Spirit gave them to speak. Yet, writers on rhetoric have found rhetoric in their writings and have made use of their writings to compose commentaries and rules. ${ }^{37}$

Ambrose first concedes the notion that sacred writers did not write with the intention of conforming to human-made rules of rhetoric. What God gave them to speak cannot be judged based on rhetorical criteria, since God is above the makers of rhetorical rules. At the same time, writers on rhetoric have identified rhetorical principles in the sacred texts, as Ambrose goes on to illustrate using the rhetorical categories of 'cause', 'subject' and 'purpose'. ${ }^{38}$ Remarkably, Ambrose combines two concepts that seem to be in conflict with one another: on the one hand, sacred writings, by virtue of their divine inspiration, are in a category by themselves as literature; on the other hand, rhetorical rules, as described by human scholars of rhetoric, can be discerned in sacred writings. Although Ambrose does not develop these ideas into a coherent theory, the essence of this combination served as the foundation for Augustine's approach to reconciling the Latin Bible with Graeco-Roman standards of artistic composition. Over the span of his life, as he wrestled with the stylistic qualities of the Bible, Augustine worked out a theology of Scripture that both acknowledged its uniqueness as a text and also made room for rhetorical and literary

Life, Writings and Legacy, ed. Andrew Cain and Josef Lössl (Burlington, VT: Ashgate, 2009): 131-40; and Graves, Jerome's Hebrew Philology, 76-127.

37 Ambrose, Ep. 21; see Saint Ambrose: Letters (tr. Mary M. Beyenka; New York: Catholic University of America Press, 1954): 115.

38 Ambrose is dependent on Philo for his formulation of these ideas, even though Philo employed these concepts as part of his allegorical exegesis and not as a way to address the artistic nature of the Bible; see Adam Kamesar, 'Ambrose, Philo, and the Presence of Art in the Bible', JECS 9 (2001): 73-103. 
art at the human level. This model became paradigmatic for the Middle Ages.

Prior to his baptism by Ambrose in 387, Augustine had been a professor of rhetoric at Carthage and Milan, having received in his youth a literary and rhetorical education similar to that of Jerome. ${ }^{39}$ Like Jerome, Augustine was at first turned away by the unattractive style of Scripture, which seemed 'unworthy in comparison with the dignity of Cicero' (Conf. 3:5:9). ${ }^{40}$ For Augustine, however, the first stage in overcoming this aversion was to emphasise content over form. ${ }^{41}$ The biblical text was 'enveloped in mysteries' (Conf. 3:5:9); it was not to be taken literally, lest the diction seem unattractive, but must be 'unfolded and revealed so as to convey a meaning' (Catech. 9:13). ${ }^{42}$ It was the content of the biblical text as revealed through Ambrose's allegorical preaching that first made Scripture believable to Augustine (Conf. 5:14:24). This disavowal of the form of Scripture would seem to leave little room for appreciating the literary quality of any specific biblical text.

Yet, even in his early stages of reflection, Augustine thought about Scripture in terms very close to artistic appreciation. In book two of $O n$ Christian Teaching (c. 396), Augustine explains his allegorical reading of Song of Songs 4:2 ('Your teeth are like a flock of shorn ewes') in aesthetic terms. In the Song, the church is addressed as a beautiful woman, and to express the same idea in straightforward language would 'give less pleasure to the audience' (Doctr. Chr. 2:6:7). ${ }^{43}$ Augustine thinks that it gives 'more pleasure' to contemplate holy men as the teeth of the church, and he speaks of the 'greatest of pleasure' that comes from visualising holy men, with their worldly burdens set aside, coming up from baptism like shorn ewes (Doctr. Chr. 2:6:7). Although 'virtually nothing is unearthed from these obscurities which cannot be found quite plainly expressed somewhere else', 'it is more pleasant to learn lessons presented through imagery' (Doctr. Chr.

39 On Augustine's 'grammatical' education, see Henri-Irénée Marrou, Saint Augustin et la fin de la culture antique (4th edn; Paris: E. de Boccard, 1958).

40 Saint Augustine: Confessions (tr. Henry Chadwick; Oxford: Oxford University Press, 1991): 40.

41 Marrou, Saint Augustine, 475.

42 St. Augustine: The First Catechetical Instruction (tr. Joseph P. Christopher; New York: Newman Press, 1978): 33.

43 Saint Augustine: On Christian Teaching (tr. R. P. H. Green; Oxford: Oxford University Press, 1999): 33. 
$2: 6: 8)$. For the early Augustine, this pleasure comes from the content of the text unfolded through allegory, not the stylistic level of the language. But once he accepted the loftiness of the ideas, he began to see artistic qualities in the text that moved in the direction of literary appreciation. This is why in his First Catechetical Instruction Augustine was able to speak of Scripture's 'marvelous sublimity' (which sounds like a literary judgment), even as he was conceding the simplicity of the language (Catech. 8:12). Even early in his career, Augustine's respect for the divine content of Scripture led him to recognise its beauty.

Still, it was not until later in life that Augustine formulated his full view that biblical texts could have their own eloquence. He expresses this position most clearly in book four of On Christian Teaching, which he completed in the late 420s. Having discussed the relative merits of wisdom and eloquence for Christian speakers, Augustine asks whether the writers of Scripture should be considered merely wise, or also eloquent. ${ }^{44}$ According to Augustine, they were both. The eloquence of biblical writers was unique and specially suited to their divine authority, just as specific types of eloquence are suitable to different people of diverse ages. It would not have been suitable for sacred writers to have used a different style, nor would it have been suitable for other writers to have written in the scriptural way.

At one moment, it appears that Augustine is using the term 'eloquence' simply to make a 'content over form' argument, when he says that Scripture's style is humble and transcends other literature not in conceit (ventositas, 'windiness') but in substance (soliditas). Content, however, is now only part of the argument. Not only does Scripture mix eloquence with obscurity so as to delight the reader by making him work to grasp the meaning, but Scripture also contains all the virtues and ornaments of eloquence that are admired by those who fancy themselves learned. Of course, human eloquence does not validate Scripture. What impresses Augustine is that Scripture uses human eloquence together with a different eloquence all its own (alteram quandam eloquentiam suam), such that eloquence is not lacking but is also not unduly prominent. 'You could visualize it as wisdom proceeding from its own home (by this I mean a wise person's

44 The entire discussion is found at Doctr. Chr. 4.6.9-4.7.21. 
heart) and eloquence, like an ever-present slave, following on behind without having to be summoned' (Doctr. Chr. 4:6:10).

Augustine proceeds to illustrate the eloquence of Scripture with several examples, first from Paul and then from Amos. Paul is said to use the figure $\mathrm{k} \lambda \dot{\mu} \mu \alpha \xi$ (Latin: gradatio) and employ the periodic style in Romans 5:3-5.45 Augustine likewise gives a lengthy description of the carefully crafted periodic construction of 2 Corinthians 11:16-30. According to Augustine, it would be tedious to examine all of the passages that demonstrate Paul's stylistic abilities, since they are so numerous (Doctr. Chr. 4:7:14). Paul was only speaking hypothetically in 2 Corinthians 11:6 when he said, 'Even if I am unskilled in speaking ...' (Doctr. Chr. 4:7:15). Paul may not have been intentionally following rhetorical rules, but eloquence certainly followed after his wisdom (Doctr. Chr. 4:7:11). As for Amos, Augustine chooses Jerome's translation of Amos 6:1-6:

My text is not that of the Septuagint, whose seventy translators, though working with the help of the Holy Spirit, seem to have rendered some passages in different ways so that the reader's attention might be alerted to the search for spiritual meaning (which is why some of their sayings - the more figurative ones - are rather obscure), but that of the translation from Hebrew into Latin made by the priest Jerome, an expert in both languages. ${ }^{46}$

Augustine describes the eloquence of Amos' speech in a way similar to his treatment of Paul. Amos is praised for elegance of expression based on his word choice, his imagery and how he constructs his argument. One may note that the traditional Latin version based on the Septuagint, although useful owing to its obscurity for uncovering hidden allegorical meanings, is not as useful as Jerome's version for appreciating the text at the literary level. Augustine summarises: 'We should therefore acknowledge that our canonical authors and teachers

45 Augustine describes Paul's use of periods in formal rhetorical terms: the phrases, in Greek $\kappa \tilde{\omega} \lambda \alpha$ and кó $\mu \alpha \tau \alpha$, are constructed into a 'period' (ambitus or cicuitus; Greek: $\pi \varepsilon p i o \delta o v)$, 'in which the parts are left hanging by the speaker's voice until the period is completed by the last clause' (Doctr. Chr. 4.7.11).

46 Doctr. Chr. 4.7.15. As we know from Augustine's letters (e.g. Epist. 28), he was at first critical of Jerome's Hebrew-based translation project. But by the end of his life (and after Jerome's death), Augustine seems to have accepted the value of Jerome's version, if only because it represented a stylistic improvement over the Old Latin. See Carolinne White, The Correspondence (394-419) Between Jerome and Augustine of Hippo (Lewiston: Edwin Mellen, 1990). 
are eloquent, and not just wise, with a kind of eloquence appropriate to the kind of persons they were' (Doctr. Chr. 4:7:21).

Instead of accepting that pagan literature was of a higher literary quality than the Bible, Augustine argued that Scripture was equal in eloquence to secular literature, but also different and unique. ${ }^{47}$ Augustine's view of the artistic element in Scripture reflects his complex views about the nature of art and custom. According to Augustine, there are two kinds of learning recognised by pagans: that which was instituted by humans, and that which already existed (or was instituted by God) and has merely been observed by humans (Doctr. Chr. 2:19:29). In one sense, principles of eloquence exist absolutely; they were not invented by teachers of rhetoric, but were observed in great speakers, ${ }^{48}$ the source of whose eloquence is natural talent, the source of which is God. Thus, one should not be surprised to see eloquence in men inspired by God (Doctr. Chr. 4:7:21). In another sense, however, language is a matter of convention. Augustine once observed that, even after all of his rhetorical training, he was still corrected in pronunciation by Italians, and he likewise corrected them (De ordine 2:17:45). ${ }^{49}$ As a north African, Augustine's pronunciation of Latin differed from what was customary in Italy (the more prestigious pronunciation), and his personal experience of this difference may have increased his awareness of the local nature of such conventions. ${ }^{50}$ In the moral sphere, Augustine recognised in the polygamy of the patriarchs a custom (consuetudo) or social practice (mos) that was blameless for those times but became unacceptable later (Doctr. Chr. 3:12:19-20). One might suggest that Augustine's sensitivity to differences in custom allowed him to see how Scripture could be artistic in its own 'different but equal' way. ${ }^{51}$

\footnotetext{
47 Marrou, Saint Augustine, 476-77.

48 The same basic point was made by Origen with reference to Paul, as preserved in Fr. 1 Cor. 15:14. According to Origen, 'Even if Paul showed knowledge of dialectical discourse, he nevertheless made use of it simply by nature, since the substance of the

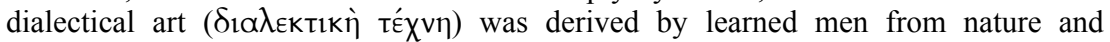
repeated usage.' See Claude Jenkins, 'Origen on 1 Corinthians', JTS 10 (1908-09): 45. 49 On Order [De Ordine] (tr. Silvano Borruso; South Bend, IN: St. Augustine's Press, 2007): 111.

50 See Christoph Schäublin, 'De doctrina christiana: A Classic of Western Culture?' in De doctrina christiana: A Classic of Western Culture, ed. Duane W. H. Arnold and Pamela Bright (Notre Dame: University of Notre Dame Press, 1995): 56-57.

51 That Augustine applied his awareness of 'custom' to the language of the Bible is especially plausible when one considers that the word consuetudo could be used with
} 
Augustine also advanced Christian thinking on the question of art in Scripture by identifying a purpose for literary crafting in the biblical text. Within the context of De doctrina christiana Book 4, where he is discussing how to present what has been learned from Scripture, Augustine naturally defines the purpose of Scripture's eloquence in rhetorical terms. After apologising for not describing the eloquence of Amos in greater detail, Augustine explains: 'But the effect of eloquence on a person of good character is not so much to instruct when painstakingly discussed as to inspire when passionately delivered' (Doctr. chr. 4:7:21). In other words, the rhetorical features of the text are meant not to teach rhetorical technique, but to inspire the hearer, that is, to rouse his emotions and move him to action. ${ }^{52}$ This view is clearly well suited to the rhetorical crafting that Augustine claims to find in Paul and Amos. The idea that Scripture's artistry has some effect on the whole person gave the Christian tradition a 'practical' reason to be concerned with the artistic quality of biblical texts. Augustine's belief that biblical books contain literary ornamentation was transmitted to the Middle Ages through scholars such as Cassiodorus, whose Commentary on the Psalms followed Augustine's lead. ${ }^{53}$

\section{Conclusion}

Considering the issue both historically and theologically, the initial Christian response of emphasising content over form captured the essential heart of the matter. The sacred writings that came to constitute the Christian Bible had not been written or collected together on the basis of any artistic criteria. That which gave unity to the scriptural collection was the divine subject matter and the religious ideology represented in the various books. The Bible was certainly not compiled

particular reference to language usage (Varro, Ling. Lat. 9.8; Cicero, Orat. 47.157; Fin. 3.40; Quint. 1.6.3; 1.6.16).

52 Cf. the function of the 'grand' style in Cicero, Orator 21.69; and Quintilian 12.10.58-59.

53 Cf. Cassiodorus: Explanation of the Psalms (2 vols.; tr. P. G. Walsh; New York: Paulist Press, 1990 and 1991). On Cassiodorus, see Curtius, European Literature, 41, 46-47, 448-50; Beryl Smalley, The Study of the Bible in the Middle Ages (Notre Dame, IN: University of Notre Dame Press, 1964): 31-32; and Martin Irvine, The Making of Textual Culture: 'Grammatica' and Literary Theory, 350-1100 (Cambridge: Cambridge University Press, 1994): 195-209. 
because it represented fine literary art in Greek, and so when pagan critics attacked the Scriptures on the basis of Greek literary criteria, early Christians made the right move when they played down the aesthetic element and stressed the message. Theologically, there was no need for early Christians to argue that the divine truth of Scripture was communicated through an artistic medium recognised by high culture. On the contrary, the biblical motif of the weaker overcoming the stronger led in the opposite direction. Given the options that were available within the culture, as a fundamental stance the 'content over form' argument was a theologically sound place to begin.

At the same time, the argument for content rather than form as it was expressed by these earliest Christians was ultimately insufficient to account for the whole of what is found in Scripture. Although some scriptural books may have been written in a simple style to avoid pretence or to communicate with a wide audience (perhaps Paul's letters), the same could not be said for every biblical book (e.g. Isaiah). Even if biblical writers did not think of themselves as producing 'art', they did produce literature that left deep impressions on the emotions, minds and wills of readers. In terms of cultural translation, Roman critics could justifiably describe these impressions in artistic terms. To categorise Scripture as bad literature with lofty inner content was especially misleading for the Old Testament, since its artistic qualities are best appreciated in the original Hebrew. In the end, although it is not necessary for scriptural books to be artistically crafted according to a given set of human conventions, there is also no reason to deny that they could be. Yet, as long as the standard for evaluation remained the great works of Graeco-Roman culture, the literary artistry of many biblical books remained hidden. But once the church became free to read the sacred writers according to their own conventions and aims, it became possible to explore both the existence and the purpose of literary art in Scripture.

Jerome's major contribution to appreciating the literary quality of Scripture is the recognition that it must in some sense be taken on its own terms. Of course, his efforts in this direction were primarily limited to the Old Testament. But Jerome successfully demonstrated that the Old Testament in the original Hebrew did in fact possess artistic merit as literature, and that it only appeared to have a low style because it was being read in translation. It is noteworthy that such an 
observation was made by a Roman and not a Greek. ${ }^{54}$ Greek culture served as the foundation for the intellectual life of the Roman Empire. Going back to the beginnings of Roman literary culture in the Third Century BC, Roman thinkers were dependent on Greek models for the creation of their own culture, as Horace said, 'Greece, the captive, made her savage victor captive, and brought the arts into rustic Latium'. ${ }^{55}$ Educated Romans were bilingual, and many, including Jerome, produced translations of Greek works in addition to writing their own. Thus, while the monocultural Greeks were content to work with their Greek translations of the Old Testament, ${ }^{56}$ the Roman Jerome, who was already accustomed to reaching into a second culture (Greek), was intellectually ready to venture into a third (Hebrew). Once Jerome entered into the thought world of Hebrew, he could see that the Hebrew Old Testament has its own way of being artistic.

The lesson that Jerome learned about the artistic quality of the Old Testament can be applied even more fully today through our knowledge of the ancient Near Eastern world in which the books of the Old Testament were written. Jerome took the Old Testament on its own terms by reading it in Hebrew, and was thereby able to appreciate it as literature. Because we now have texts from the ancient Near East that inform us regarding the literary conventions that shaped the Old Testament, we are able to read Old Testament books with an eye towards the literary genres that were operative in the times and places when those books were written. We can appreciate Hebrew poetry better by comparing it with Ugaritic poetry and taking note of how the biblical poems make use of common artistic conventions. Similar comparisons can be made for the early narratives in Genesis and Mesopotamian literary texts, the Song of Songs and Egyptian love poetry, and Lamentations and ancient city laments. ${ }^{57}$ To pay attention to genre is to acknowledge the value of Greek literary theory, but, following the tracks set by Jerome and extending them a bit further, the

54 See Adam Kamesar, Jerome, Greek Scholarship, and the Hebrew Bible (Oxford: Clarendon Press, 1993): 43.

55 Horace, Epistles 2.1.156; see Horace: Satires, Epistles and Ars Poetica (tr. H. Rushton Fairclough; Cambridge, MA: Harvard University Press, 1929): 409.

56 The initial impulse in the direction of the Hebrew text given by Origen did not bear fruit in the Greek Christian world.

57 Cf. D. Brent Sandy and Ronald L. Giese, Jr., ed., Cracking Old Testament Codes: A Guide to Interpreting the Literary Genres of the Old Testament (Nashville, TN: Broadman \& Holman, 1995). 
actual genres that we use to read the Old Testament should be ancient Near Eastern genres rather than Greek ones.

Augustine also made several important contributions to the patristic discussion on the literary quality of Scripture. First, Augustine's early reflections on the pleasure derived from unveiling the deeper meaning of Scripture (as Augustine saw it) speak to the connection between the subject matter of the text and its beauty. The literary treatise $O n$ Sublimity listed 'the power to conceive great thoughts' as one of the five sources of sublimity. ${ }^{58}$ In other words, the loftiness of the subject matter treated in a text had an impact on the aesthetic quality of the text. If one endeavours with any success to describe beautiful things, one must reach a high level of expression. Thus, because sacred writers had God and divine truth as their subject matter, this led to a kind of aesthetic quality being necessarily part of the sacred writings. If one considers God to be the most sublime of all things, then the Scriptures that speak of him must also partake in sublimity.

Another valuable contribution that Augustine made is his theoretical distinction between what is customary and what is absolute. Although Augustine lacked the linguistic abilities to appreciate, as Jerome did, the particular artistic qualities of the Old Testament in Hebrew, he nevertheless recognised that the whole question of art is wrapped up in human convention. If a text is to be considered artistically crafted, it must be artistic according to some agreed upon standard. This introduces an element of relativity and gives Augustine the freedom to make the argument that Scripture can be artistic in its own particular way. Even if biblical writings do not correspond precisely to the Graeco-Roman expectations for great literature, they can still be regarded as literarily well crafted, since the Graeco-Roman conventions are not absolute. Scripture can have its own fine style suitable to its nature.

Moreover, Augustine's balanced treatment of inspiration and convention is worthy of deeper reflection. The rhetorical art found in good speakers, although expressed according to humanly established rules, is not merely of human origin. God grants natural talent to speakers, and these speakers in turn deliver great speeches, which seem to correspond to known rules of rhetoric. But if the talent is given by

58 On Sublimity 8.1; see D. A. Russell and Michael Winterbottom, ed., Ancient Literary Criticism: The Principal Texts in New Translations (Oxford: Oxford University Press, 1972): 467. 
God, does this not imply that the 'rules' implicit in the speeches of these talented orators are divinely sanctioned? While Augustine would see God as the ultimate source of these rules of oratory, he would not grant them exclusive divine sanction, since God-given Scripture has its own eloquence that is not precisely the same as the eloquence of human orators. What this means, then, is that the God-granted talent of these orators allowed them to speak in a way that was persuasive within their own cultural environment. The spark of talent that led them to speak with charm or passion might have come from God, but the actual forms of discourse that made their speeches delightful or moving were shaped by and suited to their own cultural conventions. As with content, so also with artistic quality, the divine impulse finds expression through human conventions, so that the result is understandable in human terms and appropriate to God's purpose. Augustine points to a perfect interface between the human and the divine, which was the key theological element in his understanding of the literary quality of Scripture. 